\title{
肝癌細胞内 $\mathrm{HBc}$ 抗原および $\mathrm{HBe}$ 抗原の局在に
}

\section{関する免疫組織化学的研究}

桑原 芳弘 青山 圭一 南部 修二
井上 恭一 佐々木 博*

肝細胞癌 (HCC) に括ける癌部の B 型肝炎ウイルス (HBV) 関連抗原の陽性頻度は一般的に非癌部に比へ て低く，特に HBc 抗原が観察される機会は極めて稀 である ${ }^{1 \sim 3)}$. 今回著者らは血中 HBs 抗原陽性の HCC について，主に癌部における HBV 関連抗原の局在を 免度組織化学的手法を用いて検討し, HBV-DNA との 関連から解析を加えたので報告する。

对象および方法：対象は組織学的に HCC と診断さ れ, かつ血中 HBs 抗原陽性の46例で, RIA 法による血 中 $\mathrm{HBe}$ 抗原・抗体の検索では HBe 抗原陽性10例 (22\%)，HBe 抗体陽性15例 (32\%)，両者陰性21例 (46\%)であった． 肝組織内 HBV 関連抗原については 薄切切片全体に抽ける HBV 関連抗原陽性の肝細胞の 占める割合 (分布量) を一 $4+(-: 0 \%, 1+:<$ $5 \%, 2+:<30 \%, 3+:<80 \%, 4+: \geqq 80 \%)$ のスコアで評価した。 また，連続切片法で同一简所に 二種類の HBV 関連抗原が観察された場合には二重染 色法4を用いてその局在を確認した。

癌部で $\mathrm{HBc}$ 抗原の局在が観察された 2 症例（症例
4，6)に関しては癌部と非癌部から DNAを抽出し, southern blot hybridization 法により組織内の HBVDNA の検索をした.な和プローブとしで²Pでラベル したクローン化 HBV-DNAを使用した。

成績：血中 HBs 抗原陽性 HCC (46例) の非癌部之 癌部に拉ける $\mathrm{HBs}$ 抗原, $\mathrm{HBc}$ 抗原および $\mathrm{HBe}$ 抗原 はそれぞれ，非癌部で34例 $(74 \%) ， 19$ 例 (41\%) およ び 4 例 ( $9 \%$ ) に観察され，一方癌部では 8 例 (17\%), 2 例 (4\%) および 1 例 (2\%) に観察された。 HBs 抗原之 $\mathrm{HBc}$ 抗原の陽性頻度は共に癌部で有意に低值 （p<0.01）を示した。 また血中 $\mathrm{HBe}$ 抗原・抗体系と癌 組織部における HBV 関連抗原の局在との関連では, 血中 $\mathrm{HBe}$ 抗原陽性群 (10例) では癌部で HBs 抗原が 4 例 (40\%), HBc 抗原が 1 例 (10\%), HBe 抗原が 1 例（10\%）に観察され，血中 $\mathrm{HBe}$ 抗体陽性群 (15例) では癌部で $\mathrm{HBs}$ 抗原が 3 例 (20\%)，HBc 抗原が 1 例 (7\%) に観察されたが， $\mathrm{HBe}$ 抗原は観察されなかっ た. 両者陰性群 (21例) では癌部で HBs 抗原が 1 例 (5％)に観察されただけであった。癌部にお゙ける HBs

Table Summary of $8 \mathrm{HBsAg}$-seropositive cases in which HBsAg is localized in hepatocellular carcinoma.

\begin{tabular}{|c|c|c|c|c|c|c|c|c|c|c|c|c|}
\hline \multirow{2}{*}{$\begin{array}{l}\text { Case } \\
\text { No. }\end{array}$} & \multirow{2}{*}{ Age/Sex } & \multirow{2}{*}{$\begin{array}{l}\text { Serum } \\
\text { HBeAg/ } \\
\text { anti-HBe }\end{array}$} & \multirow{2}{*}{$\underset{\mathrm{ng} / \mathrm{ml}}{\mathrm{AFP}}$} & \multirow{2}{*}{$\begin{array}{c}\text { Liver } \\
\text { cirrhosis }\end{array}$} & \multirow{2}{*}{$\begin{array}{c}\text { Histological } \\
\text { classification }\end{array}$} & \multirow{2}{*}{$\begin{array}{l}\text { Edmondson's } \\
\text { classification }\end{array}$} & \multicolumn{2}{|c|}{$\begin{array}{c}\mathrm{HBsAg} \\
\text { localization }\end{array}$} & \multicolumn{2}{|c|}{$\begin{array}{c}\mathrm{HBcAg} \\
\text { localization }\end{array}$} & \multicolumn{2}{|c|}{$\begin{array}{c}\mathrm{HBeAg} \\
\text { localization }\end{array}$} \\
\hline & & & & & & & Non-HCC & $\mathrm{HCC}$ & Non-HCC & $\mathrm{HCC}$ & Non-HCC & $\mathrm{HCC}$ \\
\hline 1 & $54 / \mathrm{M}$ & $+1-$ & 8 & $(+)$ & $T$ & II & $2+$ & $1+$ & $1+$ & - & - & - \\
\hline 2 & $38 / \mathrm{M}$ & $+1-$ & 57900 & $(+)$ & $T$ & II & $3+$ & $1+$ & - & - & - & - \\
\hline 3 & $55 / \mathrm{M}$ & $+1-$ & 270000 & $(+)$ & $T+P$ & II & $2+$ & $1+$ & $1+$ & - & - & - \\
\hline 4 & $56 / \mathrm{M}$ & $+1-$ & 193 & $(+)$ & $T+P$ & II & $3+$ & $2+$ & $3+$ & $3+$ & $2+$ & $2+$ \\
\hline 5 & $57 / \mathrm{M}$ & $-1+$ & 18 & $(+)$ & $T$ & II & $3+$ & $2+$ & - & - & - & - \\
\hline 6 & $67 / \mathrm{M}$ & $-1+$ & 800 & $(t)$ & $T$ & II + III & $2+$ & $1+$ & $3+$ & $1+$ & $2+$ & - \\
\hline 7 & $49 / \mathrm{M}$ & $-1+$ & 60 & $(-)$ & $T+P$ & III & $3+$ & $2+$ & - & - & - & - \\
\hline 8 & $46 / \mathrm{M}$ & $-1-$ & 18700 & $(+)$ & $T$ & II & $2+$ & $1+$ & - & - & - & - \\
\hline
\end{tabular}

$\mathrm{T}:$ Trabecular, $\mathrm{P}:$ Pseudoglandular

- : $0 \%, 1+:<5 \%, 2+:<30 \%, 3+:<80 \%, 4+: \geqq 80 \%$

" 富山医科薬科大学第 3 内科 
$108: 1426$

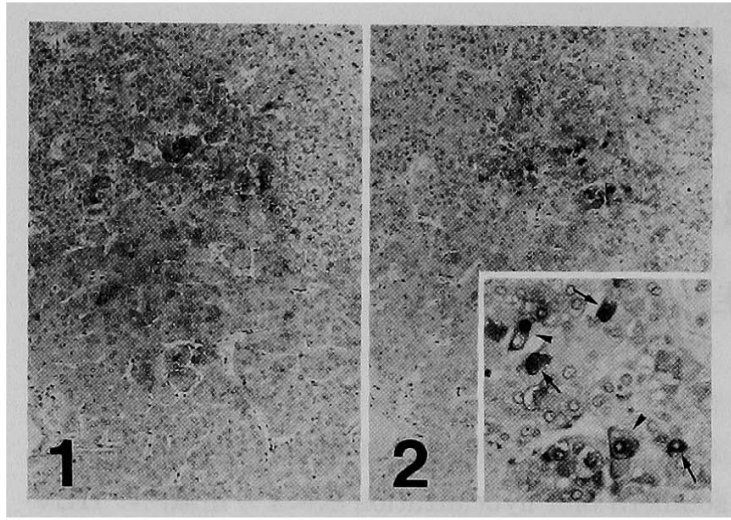

Fig. $\mathrm{HBcAg}(1)$ and $\mathrm{HBeAg}(2)$ in a case of hepatocellular carcinoma by serial section. $(\times 160)$; the inset shows cytoplasmic $\mathrm{HBeAg}$ (arrows), cytoplasmic and nuclear $\mathrm{HBeAg}$ (arrow heads) in carcinoma cells. $(\times 480)$ Indirect immunostaining counterstained with hematoxylin.

抗原の陽性頻度は血中 $\mathrm{HBe}$ 抗原陽性群が両者陰性群 に対して有意に高值を示した $(\mathrm{p}<0.01)$.

癌部に HBs 抗原が観察された 8 例の組織形態像招 よび HBV 関連抗原の局在は Table に示すごとくで, 癌部で $\mathrm{HBc}$ 抗原の局在が観察された 2 例（症例 4 ， 6)は他の症例に比し, 非癌部での $\mathrm{HBc}$ 抗原の分布量 が 3 十と高かった，血中 HBe 抗原陽性の症例 4 では 癌部で $\mathrm{HBc}$ 抗原 (Fig. 1)のみならず HBe 抗原 (Fig. 2）も主として細胞質内に観察された。細胞単位でも $\mathrm{HBc}$ 抗原保有堭煌細胞は同時に HBs 抗原ならびに HBe 抗原む保有していることが二重染色法によって 観察された，一方血中 $\mathrm{HBe}$ 抗体陽性の症例 6 の癌部 で観察された HBc 抗原は核内に局在した，HBVDNA の検索によると, 症例 4 では癌部, 非癌部共に遊 離型が, 症例 6 では癌部で組み込み型, 非癌部で遊離 型が観察された。

考案および結論：非癌部に比し癌部における HBV
29巻10昂（1988）

関連抗原の低陽性率の理由として，悪性化による HBV 関連抗原の産生抑制叫，また HBV-DNA が組み 込み後に受けるメチル化による遺伝子発現の抑制など が考党られている. PLC/PRF/5 (Alexander) 細胞の 組み込をれた HBV-DNA では, Gene Sが汪とんどか あるいは全くメチル化されないのに対し, Gene C は広 範囲にメチル化されていることが観察されて招りの， HBV-DNA の全 sequence が組み込まれているにも かかわらず PLC/PRF/5細胞で $\mathrm{HBC}$ 抗原が産生 (発 現）れない理由として，このGene Cに対するメチ ル化の選択的発現が考光られている。また臨床例にお いてもこのメチル化が癌部に打ける $\mathrm{HBc}$ 抗原の低陽 性率へ深く関与しているものと考えられる。

血中 $\mathrm{HBe}$ 抗原陽珄例の癌部でも HBV-DNA は遊 離型の場合と組み込み型の場合があるとされ7)，血中 HBV 関連抗原・抗体の出現・消失から HBV-DNA の 存在様式を規定することは困難であるが，今回の検索 結果から, (1)血中 HBe 抗原陽性で細胞質型 $\mathrm{HBc}$ 抗原 が観察され, HBV-DNA が遊離型の場合には癌部での 盛んな HBV の複製が行われ，(2)血中 $\mathrm{HBe}$ 抗体陽性 で核型 HBc 抗原が観察されたとしても，HBV-DNA が組み込み型の場合にはメチル化の関連からも, 癌部 での完全な $\mathrm{HBV}^{\mathrm{B})}$ の複製はない可能性が強いるのと 考えられた。

索引用語：肝細胞癌, $\mathrm{HBc}$ 抗原, $\mathrm{HBe}$ 抗原

文 嗝 : 1) Trevisan A, et al: J Clin Pathol 31 : $1133-1139,1978$ 2) Suzuki $\mathrm{K}$, et al: Cancer 56 : $321-327,19853)$ 岡島要, 他: 肝蔵 28 : 1497-1501，1987 4）桑原芳弘, 他：䀒臓 29 : 1013-1022, 1988 5) Omata $M$, et al: Gastroenterology $76: 279-287,1979$ 6) Miller RH, et al : Proc Natl Acad Sci USA 80 : 2534-2538, 1983 7) Bréchot C, et al: Hepatology $2: 27 \mathrm{~s}-34 \mathrm{~s}, 1982$ 8) $\mathrm{Ou} \mathrm{JH}$, et al: Proc Natl Acad Sci USA 83: $1578-1582,1986$

\title{
Immunohistochemical study of hepatitis B core and e antigens in hepatocellular carcinoma
}

\author{
Yoshihiro Kuwabara, Keiichi Aoyama, Shuji Nambu, \\ Kyoichi INOUE and Hiroshi SASAKI*
}

\footnotetext{
* Third Department of Internal Medicine, Faculty of Medicine, Toyama Medical and Pharmaceutical University (Toyama)
} 